\title{
MIR214 wt Allele
}

National Cancer Institute

\section{Source}

National Cancer Institute. MIR214 wt Allele. NCI Thesaurus. Code C82168.

Human MIR214 wild-type allele is located in the vicinity of 1q24.3 and is 109 bases in length. This allele, which encodes the MIR214 pre-miRNA, plays a role in the regulation of gene expression. Alteration in the expression of this gene is associated with the development of ovarian cancer. 